1VITL $\begin{array}{r}\text { Media Ilmiah Teknik Lingkungan } \\ \text { Volume 3, Nomor 2, Agustus 2018 } \\ \text { Artikel Hasil Penelitian, Hal. 16-20 }\end{array}$

\title{
Rehabilitasi dan Pengelolaan Hutan Rawa dan Hutan Rawa Gambut di Provinsi Kalimantan Tengah
}

\author{
Sari Marlina \\ Program Studi Teknik Lingkungan Universitas Muhammadiyah Palangkaraya \\ *email: sarimarlina9898@gmail.com
}

\begin{abstract}
ABSTRAK. Kawasan Hutan Kalimantan Tengah mencapai 10,295 juta hektar atau sekitar 67,04 \% dari total luas wilayah yang mencapai 15,357 juta hektar. Sedangkan sisanya seluas 5,062 juta hektar $(32,96 \%)$ merupakan Non Kawasan Hutan. kegiatan-kegiatan pengelolaan dan pemanfaatan sumber daya hutan sudah berlangsung selama lebih dari tiga decade, dampak yang dapat dilihat dan dirasakan secara langsung sebagai akibat kurang berhasilnya pengelolaan sumber daya hutan yang memacu laju deforestrasi dan degradasi hutan dari tahun adalah bertambah luasnya Lahan Kritis sebagai simbol rusaknya lingkungan seperti terganggunya tata air, Menurunnya fungsi hutan sebagai pengatur tata air, serta terganggunya ekosistem sebagai akibat dari penebangan hutan, land clearing dan pembuatan saluran / kanal, Meluasnya lahan-lahan tidak produktif dan Sangat potensial untuk terjadinya kebakaran hutan dan lahan dengan dampak asap. Sehingga perlu adanya dukungan dari berbagai pihak, terutama Pemerintah Daerah, Departemen Kehutanan dan seluruh Stake Holders yang dituangkan dalam bentuk Program Terpadu dan Komprehensif dari semua unsur yang terlibat.
\end{abstract}

Kata kunci: hutan, rawa, gambut, deforestasi, lahan kritis

\section{PENDAHULUAN}

Provinsi Kalimantan Tengah merupakan Provinsi yang memiliki kawasan hutan terluas di Indonesia dengan segala potensi dan karakteristiknya yang unik sebagai bagian dari bentang hutan hujan tropis dunia (world wide tropical rain forest). Berbagai kontribusi sektor kehutanan, baik langsung dan terukur maupun yang tidak langsung dan tidak terukur telah banyak memberikan andil atau peranan yang cukup significant bagi pembangunan di Kalimantan Tengah, misalnya penciptaan lapangan kerja, pembukaan wilayah "remote area", penerimaan negara dan daerah, dan lain-lain.

Namun demikian, di sisi lain, meskipun kegiatan-kegiatan pengelolaan dan pemanfaatan sumber daya hutan sudah berlangsung selama lebih dari tiga dekade, yakni sejak akhir tahun 60-an, tampaknya apa yang telah dilakukan selama kurun waktu tersebut masih jauh dari harapan, apalagi bila dikaitkan dengan tujuan mulia pembangunan kehutanan yakni "memberikan manfaat yang sebesar-besarnya bagi kemakmuran rakyat". Masalah pokok yang dihadapi sebagai akibat rusaknya fungsi ekologi dan fungsi ekosistem pada Hutan rawa dan Hutan Rawa Gambut adalah sebagai berikut.

1. Pada musim hujan terjadi penggenangan air yang terjebak dalam waktu lama (water logging) dan pada musim kemarau terjadi kekeringan sebagai akibat dari saluran / kanal yang dibangun lebih rendah dari permukaan lahan gambut dimana air yang tersedia pada lahan gambut mengalir ke saluran / kanal (over drain). 
2. Menurunnya fungsi hutan sebagai pengatur tata air, serta terganggunya ekosistem sebagai akibat dari penebangan hutan, land clearing dan pembuatan saluran / kanal. Areal ini termasuk lokasi yang cenderung dilaksanakan alih fungsi oleh pemerintah daerah untuk pembangunan di Kabupaten.

3. Meluasnya lahan-lahan tidak produktif / lahan kritis disekitar hutan rawa dan rawa gambut pada areal yang terjadi okupasi masyarakat dan menjadi tempat / areal illegal logging.

4. Sangat potensial untuk terjadinya kebakaran hutan dan lahan dengan dampak asap yang hampir melumpuhkan kegiatan ekonomi di Kalimantan Tengah, bahkan telah menjadi masalah Nasional serta menjadi sorotan Internasional karena produksi asap akibat kebakaran hutan dan lahan pada type hutan menjadi komoditi eksport ke Negara tetangga.

\section{TUJUAN PENELITIAN}

Adapun tujuannya sebagai berikut :

1. Terciptanya kondisi hutan rawa dan rawa gambut yang lestari.

2. Terbinanya wawasan masyarakat yang berada di lokasi sebagai pelestari lingkungan.

3. Meningkatnya kesejahteraan masyarakat yang berada dalam kawasan / sekitar lokasi.
4. Tersedianya lapangan kerja baru bagi masyarakat.

\section{METODE PENELITIAN}

\section{Sasaran Lokasi}

1. Lahan kritis yang ada pada Hutan Rawa dan Rawa Gambut khusunya pada lahan Eks. PLG 1 Juta Hektar yang mengalami degradasi / penurunan fungsi sebagai akibat dari kondisi spesifik kawasan tersebut, termasuk kebakaran hutan dan pembukaan lahan yang tidak terkendali.

2. Lokasi yang kurang produktif yang berada disekitar kampung / lokasi pemukiman penduduk.

3. Pada daerah-daerah khusus yang dianggap perlu dilaksanakan kegiatan rehabilitasi dan pengelolaan.

\section{Prosedur Kerja}

Kegiatan yang dilaksanakan pada penelitian ini meliputi.

1. Rapat, survey lokasi dan lain-lain.

2. Pengadaan dan Pengangkutan bibit.

3. Penanaman

4. Pemeliharaan

5. Pembuatan Plang (Papan Nama)

6. Pencegahan dan pemadaman kebakaran hutan / lahan.

7. Pembayaran untuk petani.

\section{Pembiayaan}

Berikut ini ditampilakan besaran pembiayaan penanaman 300 pohon pada luasan 1 hektar

Tabel. 1. Kegiatan dan Pembiayaan penanaman 300 pohon pada luasan 1 hektar (X Rp. 1.000) :

\begin{tabular}{|c|c|c|c|c|c|c|}
\hline \multirow{2}{*}{ Kegiatan dan Pembiayaan } & \multicolumn{5}{|c|}{ Bulan Ke- } & \multirow{2}{*}{ Total } \\
\hline & 1 & 3 & 6 & 9 & 12 & \\
\hline \multicolumn{7}{|l|}{ a. Rapat, survey dll } \\
\hline a.1 Petani & 490 & - & - & - & 240 & 730 \\
\hline a.2 Pembinan & 1.215 & - & - & - & 300 & 1.515 \\
\hline b. Bibit dan Angkutan & 1.890 & - & - & - & - & 1.890 \\
\hline \multicolumn{7}{|l|}{ c. Penanaman } \\
\hline c.1 Petani & 790 & - & - & - & - & 790 \\
\hline c. 2 Pembinan & 1.655 & - & - & - & - & 1.655 \\
\hline d. Pemeliharaan (Petani) & 80 & 80 & 80 & 80 & 80 & 400 \\
\hline \multicolumn{7}{|l|}{ e. Evaluasi \& Monitoring } \\
\hline e.1 Petani & - & 80 & 80 & 80 & 80 & 320 \\
\hline e.2 Pembinaan & - & 825 & 825 & 825 & 825 & 3.300 \\
\hline
\end{tabular}


Tabel 1. Lanjutan ...

\begin{tabular}{|c|c|c|c|c|c|c|}
\hline \multirow{2}{*}{ Kegiatan dan Pembiayaan } & \multicolumn{5}{|c|}{ Bulan $\mathrm{Ke}-$} & \multirow{2}{*}{ Total } \\
\hline & 1 & 3 & 6 & 9 & 12 & \\
\hline f. Bahan, Plang, dll & 1.000 & - & 400 & - & 400 & 1.800 \\
\hline $\begin{array}{l}\text { g. Pencegahan dan } \\
\text { pemadaman kebakaran }\end{array}$ & 790 & - & - & - & - & 790 \\
\hline $\begin{array}{l}\text { h.Pembayaran utk petani } \\
\text { h.1. harga / pohon hidup }\end{array}$ & - & 1,5 & 1,5 & 1,5 & 1,5 & 1800 \\
\hline Total & 7.920 & 1.435 & 1.835 & 1.435 & 2.375 & 15.000 \\
\hline
\end{tabular}

\section{HASIL DAN PEMBAHASAN}

Strategi yang perlu dikembangkan dalam rangka rehabilitasi dan pengelolaan pada type hutan rawa dan hutan rawa gambut di Provinsi Kalimantan Tengah, yaitu menggunakan Model Beli Tanam TUmbuh" yang diharapak akan berdampak posistif kepada masyarakat pelaksana atau petani, minimal meliputi.

1. Terdapat proses pendidikan lingkungan, sehingga mampu meningkatkan kesadaran masyarakat terhadap fungsi ekologis dan ekonomis lingkungan.

2. Membangkitkan Ínisiatif, Kretivitas dan Disiplin Diri sehingga terjadi pemulihan terhadap kepercayaan dan kemampuan diri pada masyarakat termasuk kepercayaan kepada pemerintah.

3. Keterlibatan masyarakat yang bertanggungjawab penuh dalam proses pembangunan bangsa, namun harus diberi penghargaan atas konstibusi mereka.

Selain hal-hal tersebut di atas, strategi lain di lapangan yang bisa dikembangkan antara lain.

1. Pelaksana lapangan adalah masyarakat kecil yang bermukim disekitar lokasi kegiatan.

2. Areal penanaman bisa lahan milik masyarakat atau lahan milik Negara yang terbengkalai (lahan tidak produktif).

3. Komoditi yang ditanam harus diprioritaskan jenis local atau jenis lain yang telah teruji adaptif dan memiliki prospek besar.
4. Komoditi yang ditanam maksimum 3 jenis, Satu diantaranya sebagai komoditi utama (main commodity), sedangkan komoditi kedua dan ketiga adalah jenis yang mampu dipanen cepat, sebagai sumber pendapatan tambahan petani pelaksana.

5. Penanaman dilakukan dengan tidak menerapkan "tanam satu bunuh seribu", artinya bahwa penanaman cukup dengan cara melakukan perintisan ringan sepanjang baris tanam dan pembersihan terbatas disekitar lobang tanam (no tillage). Strategi ini akan memberi ruang dan waktu bagi vegetasi alami setempat untuk tumbuh secara maksimal, sehingga tidak merubah ekosistem alam yang khas di lokasi tersebut.

6. Setiap jenis komoditi harus ditentukan unit cost per pohon sampai dengan umur 12 bulan (1 tahun) setelah tanam. Unit cost per pohon tersebut juga ditetapkan sesuai dengan umur tanaman, yaitu pada umur 3 bulan, 6 bulan, 9 bulan dan 12 bulan.

\section{Kegiatan Tahap Pertama}

1. Tersedianya Rencana Rehabilitasi dan Pengelolaan Hutan Rawa dan Rawa Gambut yang mantap dan Terarah.

2. Tersedianya Tekonologi dan Pola Rehabilitasi Hutan yang tepat guna, baik dari segi jenis tanaman dan teknik penanaman.

3. Teridentifikasi seluruh wilayah lahan kritis yang terdapat pada Hutan Rawa dan Rawa Gambut di Provinsi Kalimantan Tengah 


\section{Kegiatan Tahap Kedua}

1. Tersedianya Rencana Rehabilitasi Rehabilitasi dan Pengelolaan Hutan Rawa dan Rawa Gambut.

2. Berkembangnya Teknologi dan Pola Rehabilitasi dan Pengelolaan Hutan Rawa dan Rawa Gambut.

3. Berkembangnya / berperannya kelembagaan masyarakat dalam menunjang perekonomian dan pelestarian sumber daya alam.

\section{Kegiatan Tahap Ketiga}

1. Terehabilitasinya seluruh lahan / hutan yang rusak pada Hutan Rawa dan Rawa Gambut.

2. Peran serta masyarakat dalam pelestarian sumber daya alam hutan semakin meningkat

3. Meningkatnya kesejahteraan masyarakat.

4. Pulihnya kondisi Hutan Rawa dan Rawa Gambut sebagai suatu fungsi ekosistem dan ekologi.

\section{KESIMPULAN}

Rehabilitasi dan Pengelolaan Hutan Rawa dan Rawa Gambut adalah salah satu kegiatan dalam upaya memulihkan lahan yang rusak pada untuk mendukung proses percepatan pemulihan lahan ini perlu adanya dukungan dari berbagai pihak, terutama Pemerintah Daerah, Departemen Kehutanan dan seluruh Stake Holders yang dituangkan dalam bentuk Program Terpadu dan Komprehensif dari semua unsur yang terlibat. Misalnya perlunya peranan Balai Planologi Kehutanan dalam menata kembali lahan hutan sesuai dengan fungsinya, begitupun peranan Balai Konservasi Sumber Daya Alam dalam penyelamatan Plasma Nutfah dan lain-lain.

\section{DAFTAR PUSTAKA}

Azkha N, Analisis Timbulan, 2006. Komposisi, dan karakteristik sampah di kota Padang. Jurnal Kesehatan Masyarakat

Fitriana, 2013. Gambaran Partisipasi Ibu Rumah Tangga dalam Pengelolaan Sampah di RW 02 Kel. Tamamaung Kec. Panakkukang Kota Makassar.
Karmila, Raden. 2012. Partisipasi Perempuan dalam Pengolalaan Sampah Rumah TAngga di RW. 02 Kel. Neglasari Kec. Cibeunying Kota Bandung.

Moleong, Lexi.2014. Metodologi Penelitian Kualitatif. Bandung : PT Remaja

Nihaya. 2012. Dampak Sampah terhadap kesehatan, 6 september 2012

Suprapto. Dampak masalah sampah terhadap kesehatan masyarakat, Jurnal Mutiara Kesehatan Indonesia, 2005.

Moleong, Lexi.2014. Metodologi Penelitian Kualitatif. Bandung : PT Remaja

Suharman, E.Herwan, Y.2011. pengaruh strategi penyuluhan dan motivasi pemeliharaan kesehatan lingkungan terhadap pengetahuaan ibu rumah tangga tentang sampah. Jurnal bumi lestari, 2 agustus 2011

BPS "(Biro Pusat Statistik) dan DEPHUT (Departemen Kehutanan), 2007. Identifikasi Desa di Dalam dan di Sekitar Kawasan Hutan 2007. Kerjasama Departemen Kehutanan dan Biro Pusat Statistik. Jakarta.

BPS (Biro Pusat Statistik) dan DEPHUT (Departemen Kehutanan), 2009. Identifikasi Desa di Dalam dan di Sekitar Kawasan Hutan 2009. Kerjasama Departemen Kehutanan dan Biro Pusat Statistik. Jakarta.

Wulan, Y.C., Yurdi Y., Christian, P., Eva, W., 2004. Analisa Konflik Sektor Kehutanan di Indonesia 1997-2003. CIFOR. Bogor.

DEPHUT (Departemen Kehutanan), 2008. Statistik Kehutanan. Jakarta.

FOReTIKA (Forum Pimpinan Lembaga Pendidikan Tinggi Kehutanan), 2006. Kajian Penerimaan Perkebunan Kelapa Sawit: Implikasi bagi kebijakan fiskal dan konversi hutan sebagai strategi untuk revenue watch. Kerjasama FOReTIKA dan Yayasan Tifa. Jakarta.

Kartodihardjo, H., 1998. Peningkatan Kinerja Hutan Alam Produksi Melalui Kebijakan Penataan Institusi. Disertasi. Program Pascasarjana Institut Pertanian Bogor. Bogor. 
Kementerian Kehutanan, 2010. Rencana Kehutanan Tingkat Nasional (RKTN). Draft.

Jakarta. IDS (Institute of Development Studies), 2006. Understanding Policy Processes: A review of IDS's research on the environment. University of Sussex. UK

Kuswijayanti, E.R., 2006. Konservasi Sumberdaya Alam di Taman Nasional Gunung Merapi: Analisis Ekologi Politik. Thesis. Program Pascasarjana Institut Pertanian Bogor. Bogor.

Lahandu, J., 2007. Analisis Kebijakan Pengelolaan Akses Sumberdaya Alam oleh Masyarakat Kaili di Taman Hutan Raya Sulawesi Tengah. Thesis. Program Pascasarjana Institut Pertanian Bogor. Bogor.

Lintong, E., 2005. Resolusi Konflik Pertambangan di Taman Nasional Bogani Nani Watabone. Thesis.
Program Pascasarjana Institut Pertanian Bogor. Bogor.

Mardipriyono, B., 2004. Biaya Transaksi dan Pengaruhnya dalam Pengelolaan Hutan.

N.H.T Siahaan , 2009. Hukum Lingkungan. Jakarta

Produksi Lestari. Thesis. Program Pascasarjana Institut Pertanian Bogor. Bogor.

Sprinz, D., 2006. Long-Term Policy Problems: Definition, Origin and Responses. Potsdam Institute for Climate Impact Research. Dep. of Global Change \& Social Systems. Potsdam. Germany.

Sutton, R. 1999. The Policy Process: An overview. Working Paper No. 118. Overseas Development Institute Portland House. Stag Place London SW1E 5DP. 